\title{
Stonefly (Plecoptera) fauna of streams in a mountainous area of Central Brazil: abiotic factors and nymph density
}

\author{
Pitágoras da Conceição Bispo ${ }^{1}$ \\ Cláudio Gilberto Froehlich ${ }^{1}$ \\ Leandro Gonçalves Oliveira ${ }^{2}$
}

\begin{abstract}
The stonefly (Plecoptera) nymphs of streams of the Almas River basin, Pirenópolis, Goiás State, Central Brazil, and some abiotic factors that might affect their temporal distribution were studied. Nymphs were sampled monthly (June 1993 to July 1994) in five stations with a Surber sampler, and each sample consisted of 20 units totalling $2 \mathrm{~m}^{2}$. In each station, stream velocity, discharge, temperature, electrical conductivity and $\mathrm{pH}$ were measured in order to assess their influence on the density of nymphs. Nymphs were identified to genus level. In general, the annual variation in density of nymphs, in four stations, showed that the seasonal variation was not clearly influenced by the annual rain cycle. In the case of the one of the stations, where numbers of stonefly nymphs were low and the anthropic action high, there was a density peak in the rainy season. This peak was probably related to dilution of the organic pollution in the rainy season, improving the environmental conditions for the Plecoptera.

KEY WORDS. Plecoptera, nymphs, Central Brazil, abiotic factors, seasonality
\end{abstract}

The Plecoptera are an important order of aquatic insects, being found chiefly in running, clean and well-oxygenated waters. Biological and ecological aspects of the group are still little known in the Neotropical Region (ALBARIÑO 1997) and particularly in Brazil (FROEHLICH \& OLIVEIRA 1997). Most of the published papers have emphasized taxonomical aspects (FROEHLICH 1990, 1994).

Studies on the immatures of Brazilian aquatic insects are few in number, but important contributions have been made recently (GUAHYBA 1988; TRIVINHO-STRIXINO \& STRIXINO 1993; UIEDA \& GAJARDO 1996; OlIVEIRA \& FROEHLICH 1996). In Goiás State, these studies began in 1993, with collections in the Municipality of Pirenópolis. Part of the results are presented here. This is the first ecological study of the Plecoptera in the "cerrado" biome (Brazilian Savanna) of Goiás. The aims of this work were to study the Plecoptera nymph fauna in streams of the Almas River (Rio das Almas) basin, Pirenópolis, and to evaluate some factors that might influence their temporal distribution.

1) Departamento de Biologia, Faculdade de Filosofia Ciências e Letras de Ribeirão Preto, Universidade de São Paulo. Avenida Bandeirantes 3900, 14040-901 Ribeirão Preto, São Paulo, Brasil. E-mail: pitbispo@usp.br and cgfroeh@usp.br

2) Departamento de Biologia Geral, Instituto de Ciências Biológicas, Universidade Federal de Goiás. Campus Samambaia, Caixa Postal 131, 74001-970 Goiânia, Goiás, Brasil.

E-mail: lego@icb1.ufg.br

Revta bras. Zool. 19 (Supl. 1): 325 - 334, 2002 


\section{MATERIAL AND METHODS}

\section{Study area}

Figure 1 shows the Almas River basin. The sources of this river are located in the Sierra of the Pireneus, Pirenópolis, and comprise a number of streams descending steep slopes with stony or sandy bottoms and some pools retaining leaf accumulations. These streams run on the western slopes of the mountains and are part of the Amazon basin.

According to NIMER (1989), the study area presents a semi-humid tropical climate with a summer rainy season (higher precipitation from December to February) and a winter dry season from May to September.
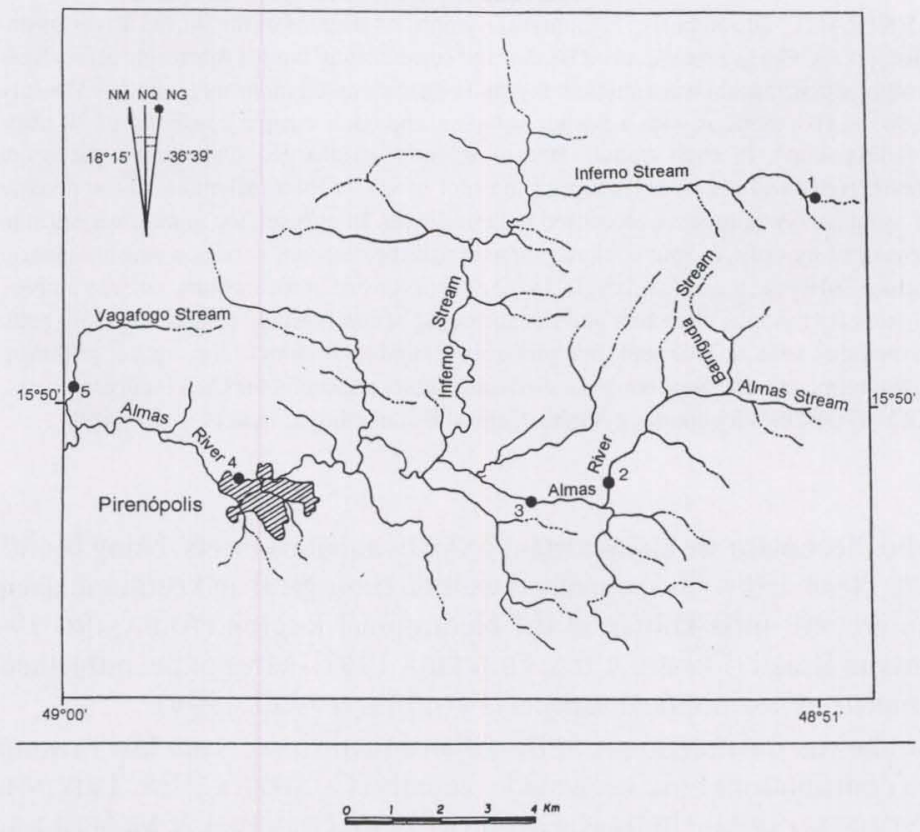

Fig. 1. Map of Almas River basin, Pirenópolis, Goiás showing sampling Stations.

\section{Samplings and Taxonomic Identification}

The samplings of the nymphs were done in five stations (Fig. 1) during 14 months - June 1993 to July 1994. Stream classification follows STRAHLER (1957).

Station 1: Inferno Stream, in first order portion, located high on the Serra dos Pireneus, at an altitude of $1100 \mathrm{~m}$ a.s.l.; the area is forested. Station 2: Almas River in a $3^{\text {rd }}$ order stretch, located within an alternative community (Frater), upstream of a camping club, at an altitude of $780 \mathrm{~m}$ a.s.l.. Station 3: Almas River, $4^{\text {th }}$ order, at $750 \mathrm{~m}$ a.s.l., within the camping club, where tourists have caused an anthropic impact. Station 4: Almas River, $4^{\text {th }}$ order, at an altitude of $730 \mathrm{~m}$ a.s.l., in a stretch that crosses the town of Pirenópolis; the anthropic impact is high, as it 
receives the town's sewage, it is also used for bathing. Station 5: Vagafogo Stream, a tributary of Almas River downstream from the town at an altitude of $710 \mathrm{~m}$ a.s.l., in a $1^{\text {st }}$ order stretch; it is located within an ecological reserve maintained by the conservation society Funatura; the area is forested.

Immatures were collected in riffles with a Surber sampler with an area of 0.1 $\mathrm{m}^{2}$ and a $0.225 \mathrm{~mm}$ mesh, following LIND (1979) and MERRITT \& CUMMINS (1996). Twenty random sampling units, totalling an area of $2 \mathrm{~m}^{2}$, were taken monthly in each station. The collected material was fixed with $5 \%$ formalin. In the laboratory, the material was sorted out and the stonefly nymphs were identified and kept in $80 \%$ ethyl alcohol.

Nymphs could be identified only to genus level since there is no comprehensive study for the sampled area associating the immatures and adults. The papers by BENEDETTO (1974) and FROEHLICH $(1969,1984)$ were used to indentify the Plecoptera genera. A representative material of the nymphs of each genus was deposited in the Museu de Zoologia, Universidade de São Paulo, Brazil (MZSP).

\section{Abiotic Factors}

In each station and sampling, air and water temperatures, discharge, water velocity, electrical conductivity and $\mathrm{pH}$ were measured. Temperatures were taken with an alcohol thermometer with a $0-50^{\circ} \mathrm{C}$ scale. Water velocity was measured by the float method and discharge by the product of mean velocity by the area of a stream cross-section (LIND 1979). The electrical conductivity was measured by a CORNING PS-17 field conductivity meter and $\mathrm{pH}$ by a CORNING PS-15 field pHmeter. Dissolved oxygen concentrations were not measured due to technical dificulties. The matrix of environmental factors was $\log$ arithmized $[\log (x+1)]$, except for the $\mathrm{pH}$ values. The stations in each month were ordinated by Principal Component Analysis (PCA), using as criterion the Pearson correlation among the variables (LUDWIG \& REYNOLDS 1988).

\section{RESULTS}

\section{Stonefly Fauna}

In this study, 3513 specimens belonging to five genera in two families were collected. Anacroneuria Klapálek, 1909 was the dominant genus, comprising $85.6 \%$ of the nymphs. The results are summarized in the table I.

Station 1: $45 \%$ (1549 specimens) of the nymphs were taken in this station. Four genera were represented: Anacroneuria, Kempnyia Klapálek, 1916, Gripopteryx Pictet, 1841 and Tupiperla Froehlich, 1969. In additional samplings, Macrogynoplax Enderlein, 1909 was also collected. Station 2: 19\% (672 specimens) of the nymphs were collected in this station; 671 individuals belonged to Anacroneuria and a single one to Kempnyia. Station 3: 9\% (324 specimens) of the nymphs were collected, all belonging to Anacroneuria. Station 4: Only 1\% (48 specimens) of all nymphs were collected, belonging to Anacroneuria. Station 5: 26\% (920 nymphs) of the nymphs were collected, and three genera were recorded, Anacroneuria, Kempnyia and Macrogynoplax. In an additional sampling, one nymph of Tupiperla was also collected. 
Table I. Number of Plecoptera nymphs (Surber, $2 \mathrm{~m}^{2}$ ) collected from June 1993 to July 1994 in the five sampling stations in streams of the Almas River basin, Pirenópolis, Goiás. (-) Not sampled.

\begin{tabular}{|c|c|c|c|c|c|c|c|c|c|c|c|c|c|c|c|}
\hline \multirow{2}{*}{ Genera } & \multicolumn{7}{|c|}{1993} & \multicolumn{7}{|c|}{1994} & \multirow{2}{*}{ - Total } \\
\hline & Jun & Jul & Aug & Sep & Oct & Nov & Dec & Jan & Feb & Mar & Apr & May & Jun & Jul & \\
\hline Station 1 & & & & & & & & & & & & & & & \\
\hline Anacroneuria & 27 & 58 & 66 & 46 & 54 & 47 & 66 & 84 & 84 & 109 & 90 & 107 & 105 & 174 & 1125 \\
\hline Kempnyia & 7 & 9 & 4 & 7 & 3 & 2 & 7 & 0 & 8 & 4 & 5 & 2 & 5 & 28 & 91 \\
\hline Gripopteryx & 6 & 5 & 1 & 7 & 28 & 7 & 14 & 23 & 14 & 9 & 14 & 14 & 1 & 2 & 145 \\
\hline Tupiperla & 0 & 17 & 16 & 17 & 46 & 7 & 14 & 9 & 4 & 1 & 2 & 2 & 1 & 52 & 188 \\
\hline Total & 40 & 889 & 87 & 77 & 131 & 63 & 101 & 116 & 118 & 123 & 111 & 125 & 112 & 256 & 1549 \\
\hline Station 2 & & & & & & & & & & & & & & & \\
\hline Anacroneuria & 46 & 10 & 39 & 94 & 88 & 85 & 72 & 13 & 9 & 23 & 42 & 28 & 54 & 68 & 671 \\
\hline Kempnyia & 1 & 0 & 0 & 0 & 0 & 0 & 0 & 0 & 0 & 0 & 0 & 0 & 0 & 0 & 1 \\
\hline Total & 47 & 10 & 39 & 94 & 88 & 85 & 72 & 13 & 9 & 23 & 42 & 28 & 54 & 68 & 672 \\
\hline $\begin{array}{l}\text { Station } 3 \\
\text { Anacroneuria }\end{array}$ & 8 & 6 & 4 & 1 & 21 & 42 & 12 & 14 & 3 & 8 & 10 & 17 & 69 & 109 & 324 \\
\hline $\begin{array}{l}\text { Station } 4 \\
\text { Anacroneuria }\end{array}$ & - & - & - & 1 & 1 & 1 & 23 & 14 & 2 & 0 & 2 & 0 & 2 & 2 & 48 \\
\hline Station 5 & & & & & & & & & & & & & & & \\
\hline Anacroneuria & 61 & 144 & 65 & 67 & 95 & 59 & 56 & 66 & 89 & 26 & 19 & 33 & 69 & 61 & 910 \\
\hline Kempnyia & 0 & 2 & 1 & 2 & 0 & 0 & 0 & 0 & 0 & 0 & 0 & 3 & 1 & 0 & 9 \\
\hline Macrogynoplax & 0 & 0 & 0 & 1 & 0 & 0 & 0 & 0 & 0 & 0 & 0 & 0 & 0 & 0 & 1 \\
\hline Total & 61 & 146 & 66 & 70 & 95 & 59 & 56 & 66 & 89 & 26 & 19 & 36 & 70 & 61 & 920 \\
\hline Grand total & 156 & 251 & 196 & 243 & 336 & 250 & 264 & 223 & 223 & 180 & 184 & 206 & 307 & 496 & 3513 \\
\hline
\end{tabular}

The seasonal density of nymphs in each station from June 1993 to July 1994 are presented in figures $3 \mathrm{~B}-\mathrm{F}$. In station 1 , the abundance variations during the 14 months were small, except for a conspicuous peak in July 1994. The smallest abundance (40 specimens) was registered in June 1993, and the largest (256) in July 1994. In station 2, there was a fall in abundance in July 1993 and a subsequent increase in August 1993; between September and December 1993 the abundance stayed high. In January and February 1994 the abundance dropped and, starting from March, it increased, reaching a high value in July 1994. The largest abundance, 94 individuals, occurred in September 1993 and the smallest, 9 individuals, in February 1994. In station 3, there was a small peak in November 1993, and the largest abundance ocurred in June and July 1994. The abundance varied from 1 individual in September 1993 to 109 individuals in July 1994. In station 4, where there is a strong anthropic influence, including the discharge of organic sewage, the density was low; an abundance peak occurred in the rainy season, December 1993 and January 1994 (Fig. 3E). The highest number collected was 23 nymphs in December 1993; in March and May 1994 no nymph was collected. In station 5, there was a peak in July 1993 and then oscillating values along the year. Numbers varied from 146 individuals in July 1993 to 26 in March 1994.

\section{Abiotic Factors}

The records of abiotic factors in each sample were ordinated in a space of two dimensions, according to PCA, based on the physical and chemical factors (Fig. 2 ). The velocity, discharge and $\mathrm{pH}$ of the water were positively correlated with the 
first component, that explained $43.08 \%$ of the variability. The factors temperature of the water and rainfall were negatively correlated with the second component that explained $25.90 \%$ of the variability (Tab. II).

Table II. Coefficients of the first two principal components for the abiotic factors recorded from June 1993 to July 1994 in the five sampling stations in the Almas River basin, Pirenópolis, Goiás.

\begin{tabular}{lcr}
\hline \multicolumn{1}{c}{ Eigenvectors } & Component I & Component II \\
\hline Water Temperature $\left({ }^{\circ} \mathrm{C}\right)$ & 0.1658 & -0.4835 \\
Water Velocity $(\mathrm{m} / \mathrm{s})$ & 0.5700 & -0.0987 \\
Discharge $\left(\mathrm{m}^{3} / \mathrm{s}\right)$ & 0.4837 & -0.1798 \\
$\mathrm{pH}$ & 0.4631 & 0.4421 \\
Electrical Conductivity $(\mu \mathrm{S} / \mathrm{cm})$ & 0.3899 & 0.3643 \\
Precipitation $(\mathrm{mm})$ & 0.1932 & -0.6293 \\
Eigenvalue & 2.5850 & 1.5540 \\
\% of variance & 43.0800 & 25.9000 \\
\hline
\end{tabular}

The average and standard deviation of the abiotic factors registered in each station from June 1993 to July 1994 are shown in table III. The regional temperature and rainfall from June 1993 to July 1994 are presented in figure 3A.

Table III. Mean and standard deviation (SD) of the abiotic factors recorded in sampling stations 1, 2, 3, 4 and 5, from June 1993 to July 1994 in Almas River basin, Pirenópolis, Goiás.

\begin{tabular}{|c|c|c|c|c|c|c|c|c|c|c|}
\hline \multirow{2}{*}{ Abiotic factors } & \multicolumn{2}{|c|}{ Station 1} & \multicolumn{2}{|c|}{ Station 2} & \multicolumn{2}{|c|}{ Station 3} & \multicolumn{2}{|c|}{ Station 4} & \multicolumn{2}{|c|}{ Station 5} \\
\hline & Mean & SD & Mean & SD & Mean & SD & Mean & SD & Mean & SD \\
\hline Water Temperature $\left({ }^{\circ} \mathrm{C}\right)$ & \multicolumn{2}{|c|}{$18.61 \pm 1.21$} & \multicolumn{2}{|c|}{$19.07 \pm 1.78$} & \multicolumn{2}{|c|}{$20.49 \pm 2.10$} & \multicolumn{2}{|c|}{$20.41 \pm 2.60$} & \multicolumn{2}{|c|}{$20.64 \pm 1.99$} \\
\hline Air Temperature $\left({ }^{\circ} \mathrm{C}\right)$ & \multirow{2}{*}{\multicolumn{2}{|c|}{$20.61 \pm 1.92$}} & \multicolumn{2}{|c|}{$21.25 \pm 3.76$} & \multicolumn{2}{|c|}{$22.61 \pm 3.22$} & \multicolumn{2}{|c|}{$22.00 \pm 4.38$} & \multicolumn{2}{|c|}{$22.07 \pm 2.63$} \\
\hline Water Velocity $(\mathrm{m} / \mathrm{s})$ & & & \multicolumn{2}{|c|}{$0.48 \pm 0.14$} & \multicolumn{2}{|c|}{$0.66 \pm 0.25$} & \multicolumn{2}{|c|}{$0.83 \pm 0.25$} & \multicolumn{2}{|c|}{$0.38 \pm 0.13$} \\
\hline Discharge $\left(\mathrm{m}^{3} / \mathrm{s}\right)$ & \multicolumn{2}{|c|}{$\begin{array}{l}0.29 \pm 0.08 \\
0.04 \pm 0.02\end{array}$} & \multicolumn{2}{|c|}{$0.64 \pm 0.38$} & \multicolumn{2}{|c|}{$0.77 \pm 0.58$} & \multicolumn{2}{|c|}{$3.09 \pm 2.39$} & \multicolumn{2}{|c|}{$0.26 \pm 0.18$} \\
\hline $\mathrm{pH}$ & \multicolumn{2}{|c|}{$7.41 \pm 0.27$} & \multirow{2}{*}{\multicolumn{2}{|c|}{$\begin{array}{c}8.31 \pm 0.18 \\
10-29\end{array}$}} & \multirow{2}{*}{\multicolumn{2}{|c|}{$\begin{array}{c}8.42 \pm 0.23 \\
20-39\end{array}$}} & \multicolumn{2}{|c|}{$\begin{array}{c}8.24 \pm 0.21 \\
10-29\end{array}$} & \multicolumn{2}{|c|}{$7.54 \pm 0.21$} \\
\hline Electrical Conductivity $(\mu \mathrm{S} / \mathrm{cm})$ & \multicolumn{2}{|c|}{$0-19$} & & & & & 10 & -29 & $10-$ & -29 \\
\hline
\end{tabular}

Conductivity was low in the streams of the Pirenópolis area, varying from $<10$ to $40 \mu \mathrm{S} / \mathrm{cm}$. The $\mathrm{pH}$ varied between 6.9 and 7.8 in the $1^{\text {st }}$ order streams and from 7.9 to 8.8 in Almas River ( $3^{\text {rd }}$ and $4^{\text {th }}$ order).

In the Almas River basin, the station that with the largest seasonal water temperature variation, $9.5^{\circ} \mathrm{C}$, was the most open one (Station 4 ); the other stations were shaded by trees in different degrees and the temperature variation was smaller, $6.5^{\circ} \mathrm{C}$ or less. As water temperatures were taken at different times during the day in the various stations, only seasonal variations were considered. The regional variation in the monthly averages of air temperature averages was $9.2^{\circ} \mathrm{C}$.

\section{DISCUSSION}

The first PCA axis (Fig. 2) can be considered as representative of the spatial heterogeneity of the environmental variables; this axis was influenced positively by the water velocity, discharge and $\mathrm{pH}$. The dispersion of the records of abiotic factors 


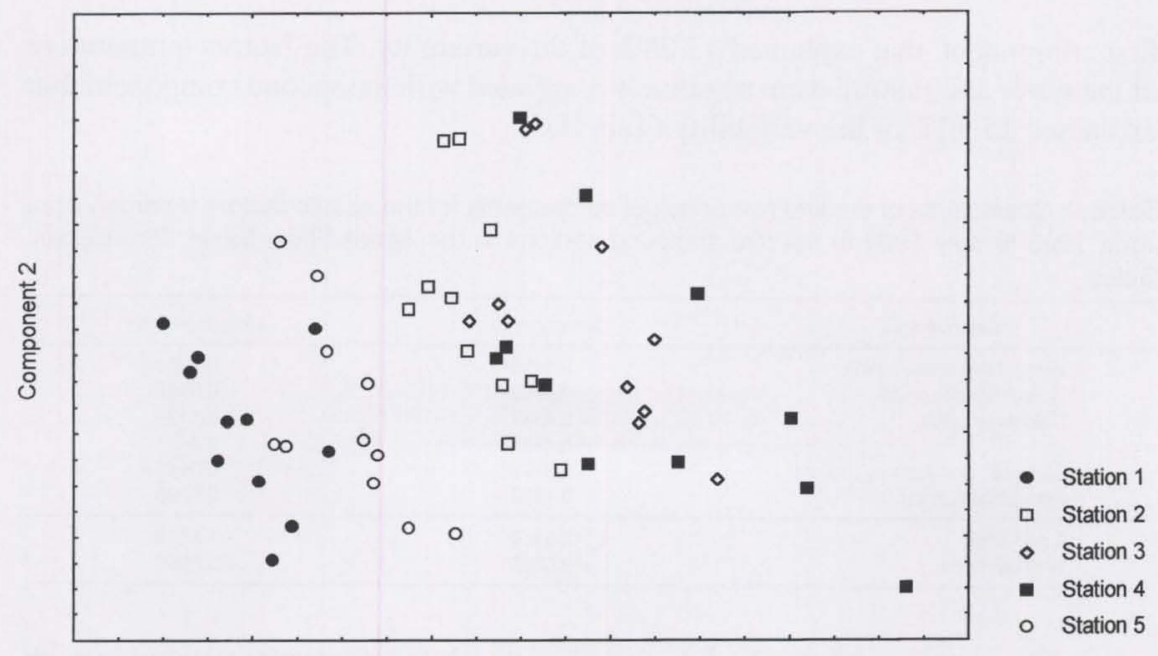

Component 1

Fig. 2. PCA ordination of the samples, based on abiotic factors recorded from June 1993 to July 1994 in the five sampling stations in the Almas River basin, Pirenópolis, Goiás.

in each sample, considering the first PCA axis, was coincident with the stream order and degree of anthropic action. The second PCA axis can be considered as representative of the temporal heterogeneity of the environmental variables; this axis was influenced negatively by the rainfall and temperature. As regards discharge and velocity, they should increase with higher rainfall, but in field measurements the correlation is not always clear, because rainfall is usually given in monthly totals and the field measurements reflect conditions in the sampling day (OLIVEIRA \& FROEHLICH 1997). The stoneflies had a large reduction in nymph density in stretches with a pronounced anthropic influence, larger stream order and higher scores for the first PCA axis. The factors water velocity, discharge and $\mathrm{pH}$ (summarized by the first PCA axis) are redundant with stream order and anthropic action. The increase in the size of the stream was coincident with the increase in the anthropic influence, making it difficult to separate which of the two influenced more the decrease in density. However, the influence of the anthropic action (organic pollution) was probably a very important factor in the variation of densities among the stations (MCCAFFERTY 1981; WIELGOSZ et al. 1982; ROSENBERG \& RESH 1993; GILLER \& MALMQUIST 1998). The organic enrichment due to the discharge of organic sewage in the system can decrease the dissolved oxygen concentration and can cause the nymph gills to become covered with fine particles, hindering gaseous exchanges. The decrease in abundance of nymphs observed where the anthropic actions are more pronounced can be related to both effects (BISPO et al. 2002).

Rainfall in the "cerrado" region is highly seasonal. The increased water velocity and flow rate during the rainy season may be considered the main determinant of the temporal variation in benthic organisms of mountain streams. Sudden increases in flow 


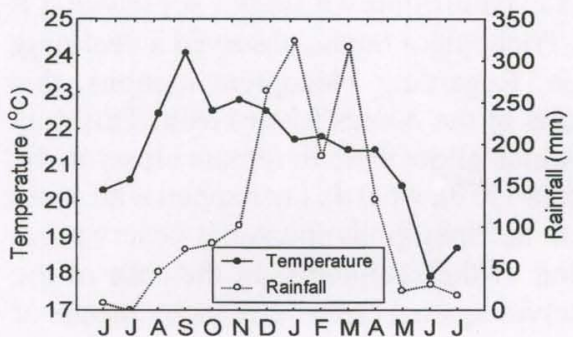

A: Temperature and Precipitation

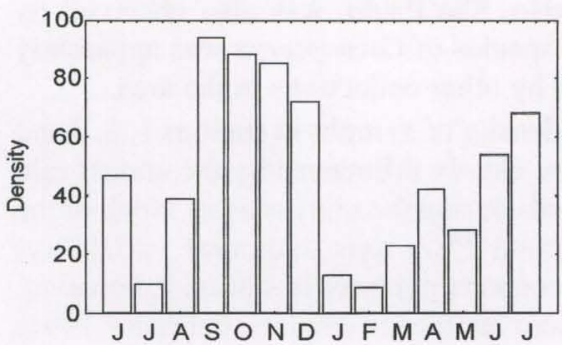

C: Station 2

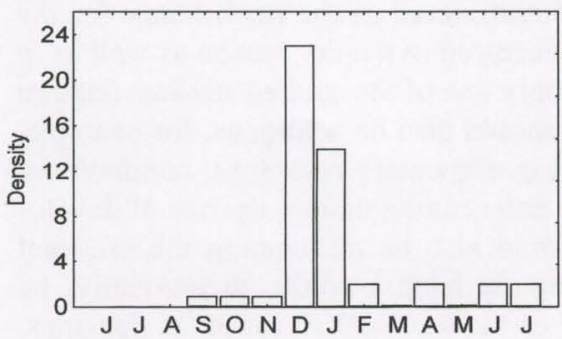

E: Station 4

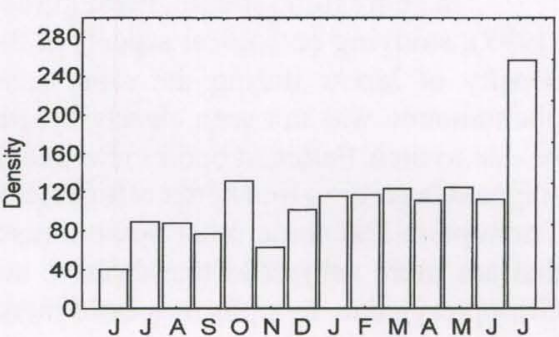

B: Station 1

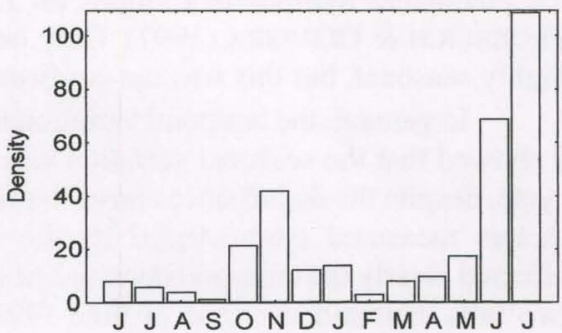

D: Station 3

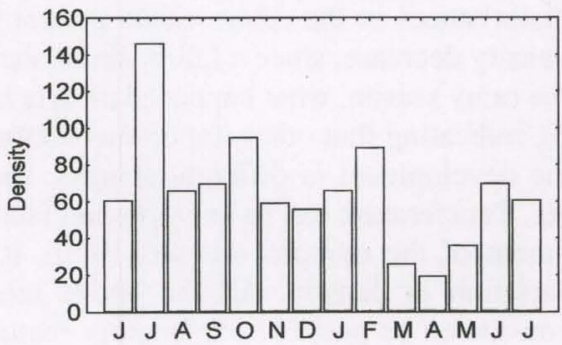

F: Station 5

Fig. 3. (A) Average monthly values of rainfall (circle) and temperature (dots) for Pirenópolis, from June 1993 to July 1994; (B-F) monthly Plecoptera densities (Surber: $2 \mathrm{~m}^{2}$ ) collected in Stations 1, 2, 3, 4 and 5, Almas River basin, Pirenópolis, Goiás from June 1993 to July 1994.

rate during the rainy season may lead to stone rolling and consequent removal of organisms, reducing their density (BOON et al. 1986; FLECKER \& FEIFAREK 1994; ROSSER \& PEARSON 1995; OLIVEIRA et al. 1997). On the other hand, rapid recolonization by these organisms may occur after the disturbance. Therefore, the density recorded each month depends, among other factors such as life cycle, availability of food resources, etc., on the number of days after the last conspicuous rain peak (FLECKER \& FEIFAREK 1994). The more days passing since the last disturbance, the more time is available for the recovery of the fauna. 
In Pedregulho stream, Pedregulho, São Paulo State, OLIVEIRA \& FrOEHLICH (1997), studying ecological aspects of the Trichoptera fauna, observed a declining density of larvae during the rainy season. Regarding Plecoptera nymphs, this phenomenon was not seen clearly in streams of the Almas River basin. This may be due to their flattened bodies (Perlidae) which allow them to remain closer to the stagnant layer or to find better refuges (HYNES 1970), what do not happen with some Trichoptera and some other aquatic insects in Pirenópolis (personal observation) that are more subject to the abrasive action of the sediments. In the case of the Gripopterygidae, nymphs may hold themselves against rapid currents by means of their strong tarsal claws or they may choose microhabitats with reduced currents, such as leaf packs retained by obstacles (FROEHLICH 1969). A non-seasonal pattern for Plecoptera nymphs in Campos do Jordão, São Paulo, was also observed by FROEHLICH \& OLIVEIRA (1997). Only one species of Gripopteryx was apparently highly seasonal, but this was not confirmed by other collections in the area.

In general, the temporal variation in density of nymphs in stations 1, 2, 3 and 5 showed that the seasonal variation was not clearly influenced by the annual rain cycle, despite the disturbance caused by floods during the rainy season. None of the factors measured (summarized by the second PCA axis, temporal variability) affected clearly the temporal densities of Plecoptera nymphs. In station 2, however, two falls in abundance (one in June 1993 and another in January-February 1994) were observed. In station 3, abundances fell in September 1993 and in February 1994, but these were not so clear due to smaller densities. The environmental disturbances in the rainy season cannot be considered as the main factor for the density decrease, since a fall in abundance occurred in the dry season as well as in the rainy season, what happened clearly in only one of the studied stations (station 2), indicating that other importants factors should also be acting, as, for example, the development of different cohorts, varying alimentary resources, competition, etc. Temperature can be an important factor determining mainly the rate of development of the nymphs (HYNES 1970), it could also be influencing the seasonal variation in density. All the above mentioned factors could, theoretically, be considered as possible explanatory factors of the seasonal variation of densities. Possibly these and other factors may acting together and they could be masking the individual effects on the density.

In the case of station 4 , where numbers of stonefly nymphs were low, there was a density peak in the rainy season. This peak is probably related to dilution of the organic pollutants in the rainy season, improving the environmental conditions for the nymphs. On the other hand, in the dry season, no specimens were collected in some months and in others the densities were very low, probably because of the higher the pollutant concentrations in this season. At this station, a peak in abundance was observed at the beginning of the rainy season.

It is important to note that during the dry season there is a tendency towards an increase in insect density. According to DINIZ-FILHO et al. (1998), this effect may be related to a reduction in the availability of habitat area due to a reduction in water level, with a consequent increase in aggregation among individuals. On the other hand, the increased flow rate during the rainy season might reduce densities 
by removing individuals and by increasing the available area. It is important to recall that most of the Plecoptera nymphs collected in Pirenópolis belong to the perlids, as they are generalist predators, the increase in their density could generate another factor, competition, that could also influence densities.

The life cycles of insects in temperate climates tend to be well-marked seasonally and many species present diapause as an adaptation to face periods with severe temperatures (HARPER \& HYNES 1970; HARPER et al. 1991; HARPER et al. 1993). In temperate regions, the emergence of adults of Plecoptera can be synchronized into short periods (HYNES 1976), what could affect the nymph densities. In Pirenópolis, the adults of most of the species, fly the along the year, but emergence peaks take place during the warm-rainy season, see BISPO et al. (in this volume). To evaluate how much the life cycle could be influencing the density of nymphs, we need more information that should include a seasonal analysis of the size classes, for the accompaniment of the different cohorts. Considering that the peaks of adult emergence in Pirenópolis occur in the warm rainy season, a conspicuous fall in nymph density could occur at the same time. In the present study, a conspicuous fall of nymph abundance in the rainy season occurred clearly only in station 2 , but this was also observed in the dry season.

In summary, the seasonal variations in density could be determined by a number of factors. In Pirenópolis, the environmental seasonality determined by the rain cycle seems not to be the most important factor acting on nymph densities. Probably, deterministic factors such as variations in the life cycle, alimentary resources, competition, etc., acting together, should also be considered as possible explanatory factors of the temporal variation in nymph densities. A longer duration study and more information on the life cycles, biology and environmental seasonality are necessary for more definite conclusions.

ACKNOWLEDGEMENTS. To FUNAPE-UFG, for financial support during field work; to CAPES and to FAPESP (proc. 98/11074-3) for scholarships to the first author; to CNPq for a research fellowship to the second (301247/96-0) and third (300833/98-9) authors.

\section{REFERENCES}

Albariño, R.J. 1997. Spatial distribution of Plecoptera from an Andean-Patagonic lotic environment in Argentina. Rev. Brasil. Biol. 57 (4): 629-636.

BenedetTo, L. 1974. Clave para la determinacion de los plecopteros Sudamericanos. Stud. Neotrop. Fauna Environ. 9: 141-170

Bispo, P.C.; C.G. Froehlich \& L.G. Oliveira. 2002. Spatial distribution of Plecoptera nymphs in streams of a mountainous area of central Brazil. Rev. Brasil. Biol. 62 (in press).

Boon, P.J.; B.P. JuPP \& D.G. LEE. 1986. The benthic ecology of rivers in the Blue Mountains (Jamaica) prior to construction of a water regulation scheme. Arch. Hydrobiologie/Suppl. 74: 315-355.

Diniz-FilHo, J.A.F.; L.G. Oliveira \& M.M. Silva. 1998. Explaining the beta diversity of aquatic insects in "cerrado" streams from Central Brazil using multiple Mantel Test. Rev. Brasil. Biol. 58 (2): 223-231.

FLECKER, A.S. \& B. FEIFAREK. 1994. Disturbance and temporal variability of invertebrate assemblages in two Andean streams. Freshw. Biol. 31: 131-142.

FroenLich, C.G. 1969. Studies on Brazilian Plecoptera 1. Some Gripopterygidae from the Biological Station at Paranapiacaba, State of São Paulo. Beitr. Neotrop. Fauna 6 (1): 17-39.

Revta bras. Zool. 19 (Supl. 1): $325-334,2002$ 
1984. Brazilian Plecoptera 4. Nymphs of perlid genera from southeastern Brazil. Annals Limnol. 20 (1-2): 43-48.

1990. Brazilian Plecoptera 6. Gripopteryx from Campos do Jordão, State of São Paulo (Gripopterygidae). Stud. Neotrop. Fauna Environ. 25 (4): 235-247.

1994. Brazilian Plecoptera 8. On Paragripopteryx (Gripopterygidae). Aquatic Insects 16 (3): 1-13.

Froehlich, C.G. \& L.G. Oliveira. 1997. Ephemeroptera and Plecoptera nymphs from riffles in low-order streams in southeastern Brazil, p. 180-185. In: P. LANDOLT \& M. SARTORI (Eds). Ephemeroptera \& Plecoptera: Biology-Ecology-Systematics. Fribourg, MTL, XI + 569p.

GilleR, P.S. \& B. MALMQVist. 1998. The Biology of Streams and Rivers. Oxford, University Press, VIII+296p.

GuAHYBA, R.R. 1988. Contribuição ao estudo das formas imaturas da ordem Trichoptera Kirby, 1813, da Represa dos Ciganos, RJ (Insecta). Acta Limnol. Brasil. 2: 751-769.

HARPER, P.P. \& H.B.N. HyNES. 1970. Diapause in the nymphs of Canadian winter stoneflies. Ecology 51: 925-927.

HARPER, P.P.; M. LAUZON \& F. HARPER. 1991. Life cycles of 12 species of winter stoneflies from Québec (Plecoptera; Capniidae and Taeniopterygidae). Can. Jour. Zool. 69: 787-796.

HaRPER, P.P.; L. Lesage \& M. LaUzon. 1993. The life cycle of Podmosta macdunnoughi (Ricker) in the Lower Laurentians, Québec (Plecoptera: Nemouridae), with a discussion on embryonic diapause. Can. Jour. Zool. 71: 2136-2139.

HyNES, H.B.N. 1970. The Ecology of Running Waters. Liverpool, University Press, XXIV+555p. . 1976. Biology of Plecoptera. Annu. Rev. Entomol. 21: 135-153.

Lind, O. T. 1979. Handbook of Common Methods in Limnology. The C.V. Mosby Company, 199p LUDWIG, J.A \& J.F. REYNOLDS. 1988. Statistical Ecology. A primer on methods and computing. New York, John Wiley \& Sons, XVIII+337p.

MCCAFFERTY, W.P. 1981. Aquatic Entomology: The Fishermen's and Ecologist's Ilustrated Guide to Insects and Their Relatives. London, Jones and Bartlett Publishers, XVI+448p.

Merritt, R.W. \& K.W. Cummins. 1996. An Introduction to the Aquatic Insects of North America. Dubuque, Kendall/Hunt Publ. Company, $3^{\text {rd }}$ Edition, XIII+862p.

NIMER, E. 1989. Climatologia do Brasil. Rio de Janeiro, IBGE, 421p.

OliveirA, L.G. \& C.G. FroeHLiCH. 1996. Natural history of three Hydropsychidae (Trichoptera, Insecta) in a "cerrado" stream from northeastern São Paulo. Revta bras. Zool. 13 (3): 755-762.

- 1997. The Trichoptera (Insecta) fauna of a "cerrado" stream in Southeastern Brazil. Naturalia 22: 183-197.

OliveirA, L.G.; P.C. BISPO \& N.C. SÁ. 1997. Ecologia de comunidades de insetos bentônicos (Ephemeroptera, Plecoptera e Trichoptera), em córregos do Parque Ecológico de Goiânia, Goiás, Brasil. Revta bras. Zool. 14 (4): 876-876.

RoSENBERG, D.M. \& V.H. RESH. 1993. Freshwater Biomonitoring and Benthic Macroinvertebrates. London, Chapman \& Hall, IX+488p.

Rosser, Z.C \& R.G. PEARson. 1995. Responses of rock to physical disturbance in two Australian tropical rainforest streams. Jour. N. Amer. Benthol. Soc. 14 (1): 183-196.

STRAHLER, H.N. 1957. Quantitative analysis of watershed geomorphology. Amer. Geophys. Unio Trans. 33: 913-920.

Trivinho-StrixinO, S. \& G. StRIXINO. 1993. Estrutura de comunidades de insetos aquáticos associados à Pontederia lanceolata Nuttal. Rev. Brasil. Biol. 53 (1): 103-111

Uieda, V. S. \& I. C. S. M. Gajardo. 1996. Macroinvertebrados perifíticos encontrados em poções e corredeiras de um riacho. Naturalia 21: 31-47.

Wielgosz, S.; G. Zoltowski \& B. KUKLinSKA. 1982. The effect of organic sewage on the lithon zoocenosis in the Lyna River. Ekol. Polska 30: 187-203.

Received in 23.III.2001; accepted in 05.VII.2002. 